\title{
Strategi Personal Branding Musisi Pop Jawa Melalui Media Sosial
}

\author{
Dadang Dwi Septiyan \\ Prodi Pendidikan Seni Pertunjukan, Universitas Sultan Ageng Tirtayasa, Kota Serang, Banten, Indonesia \\ ${ }^{(*)} \bowtie$ (e-mail) dadang.vivaldi@untirta.ac.id ${ }^{1}$
}

\begin{abstract}
Abstrak
Kemajuan teknologi informasi dan media sosial kini semakin meningkat. Hal ini memudahkan siapapun untuk membentuk personal brand melalui media sosial. Memiliki identitas yang menarik tentu wajib dimiliki seorang musisi, entah itu identitas diri ataupun identitas karya. Tujuan penelitian ini untuk mengetahui dan memahami strategi personal branding musisi melalui media sosial. Penelitian ini menggunakan metode kualitatif dengan teknik pengumpulan data yaitu wawancara dan melakukan observasi dan melakukan tinjauan literatur. Data yang didapatkan kemudian dianalisis menggunakan teknik analisis yaitu memilah-milah data, mereduksi data, peringkasan, dan penyajian data. Hasil temuan dari penelitian ini menunjukkan bahwa strategi personal branding musisi melalui media sosial khususnya Instagram, dengan menggunakan indikator yang terdiri dari 7 klasifikasi yang dipinjam dari konsep Mateusz Grzesiak. Hasil penelitian menyebutkan bahwa strategi personal branding yang dilakukan oleh beberapa sampel musisi memiliki karakter, authenticity (keaslian), integritas, specialization, distinctiveness, relevant personal branding, dan performance melalui media Instagram maupun dalam kesehariannya.
\end{abstract}

Kata kunci: Personal branding; instagram; strategies; musisi; pop jawa.

\begin{abstract}
Advances in information technology and social media are now increasing. This makes it easier for anyone to form a personal brand through social media. Having an attractive identity is a must for a musician, whether it's self-identity or work identity. The purpose of this study is to find out and understand the personal branding strategy of musicians through social media. This study uses qualitative methods with data collection techniques, namely interviews and observing and conducting a literature review. The data obtained were then analyzed using analytical techniques, namely sorting out data, reducing data, summarizing, and presenting data. The findings of this study are that the personal branding strategy of musicians through social media, especially Instagram, uses indicators consisting of 7 classifications borrowed from Mateusz Grzesiak's concept. The results of the study stated that the personal branding strategy carried out by several samples of musicians had values, characters, goals, methods, dialectics, visualizations, media, awareness levels, challenges, cultural models, and strategies each through Instagram media and in their daily lives.
\end{abstract}

Keywords: personal branding; instagram; strategies; musician; javanese pop.

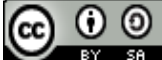

This work is licensed under a Creative Commons Attribution-ShareAlike 4.0 International License.

Copyright @ 2021 Dadang Dwi Septiyan

\section{Proses Artikel}

Diterima 03-11-2021; Revisi 07-12-2021; Terbit Online 19-12-2021 


\section{Pendahuluan}

Media sosial sudah bukan hal yang baru lagi bagi brand. Sejak era Friendster, brand sudah turut terjun dengan membuat profil di situs tersebut. Tahun 2010 menjadi puncak brand berbondong-bondong berpindah ke Facebook. Hingga awal 2011 hampir lebih dari 100 brand besar di Indonesia memiliki Facebook Page. Sejak akhir 2011, banyak brand yang memulai melebarkan kanal komunikasinya dengan Twitter dan Instagram. Hampir setiap harinya dapat dijumpai promosi brand baik produk maupun personal di Instagram khususnya. Entah itu melalui akun pribadi atau memanfaatkan jasa para buzzer (Mayfield, 2008).

Proses branding adalah proses penting dalam pemasaran, begitu juga dalam pengembangan citra yang berkaitan dengan pemberian identitas personal dari suatu merek (McNally, David \& Speak, 2004). Brand sendiri dapat diartikan sebagai penyimbolan segala sesuatu yang berhubungan dengan informasi mengenai suatu perusahaan, produk atau jasa bahkan personal. Brand bukan sekadar nama. Brand adalah 'payung' yang merepresentasikan produk atau layanan, perusahaan, orang atau bahkan negara. Brand merupakan cerminan value yang diberikan kepada pelanggan. Value artinya adalah perbandingan antara hal-hal yang didapat dan diberikan terhadap suatu brand (Kartajaya, 2009).

Dalam membangun sebuah personal brand, seseorang membutuhkan media/alat penghantar pesan yang kemudian dapat dijadikan saluran informasi dalam sebuah proses pembentukan personal brand. Saluran tersebut memiliki karakteristiknya masing-masing. Dalam melakukan kegiatan personal branding, seseorang harus mampu memilih saluran mana yang mampu dan sesuai dalam proses penyampaian pesannya karena menurut Rampersad ketika membangun personal brand apabila dikombinasikan dengan sarana yang hebat dan tepat, akan memunculkan kinerja puncak dan menciptakan dasar yang stabil bagi keandalan, kredibilitas, dan kharisma diri. Seseorang harus dapat memilih dan membuat target pasar yang sangat jelas bagi pesan personal brand nya. Selain itu seseorang yang hendak membangun personal brand juga haruslah memilih saluran branding yang tepat untuk mengkomunikasikan personal brand nya secara efektif (Rampersad, 2008, p. 132).

Penggunaan sosial media saat ini difungsikan sebagai sarana informasi dan komunikasi utama bagi manusia dan masyarakat Indonesia. Media sosial membuka peluang besar bagi pembentukan personal branding yang memiliki dampak besar bagi perkembangan profesi. Personal branding tidak hanya terjadi dalam ruang dan waktu nyata, namun juga terjadi di dalam ruang maya, salah satunya media sosial. Namun penggunaan media sosial ini masih belum diminati untuk kalangan musisi sebagai media untuk membranding dirinya. Personal branding merupakan proses membawa skill, kepribadian, dan karakter individu untuk kemudian dapat mengemasnya menjadi sebuah identitas yang memiliki kekuatan.

Mudahnya jalur komunikasi secara aktif di media sosial dengan fitur-fitur yang dapat menampilkan identitas, data diri, dan aktivitas melalui foto atau video, merupakan peluang yang harus dimanfaatkan untuk mengembangkan diri. Salah satunya musisi yang bergelut dengan dunia pertunjukan yang tentu memerlukan sebuah media untuk menampilkan eksistensi dan aktivitas dirinya sebagai musisi melalui media sosial. Aktivitas yang ditampilkan seperti menampilkan hasil karya, video cover, video saat pertunjukan, atau menampilkan ketika proses latihan, yang tentu ini akan membuka peluang orang lain untuk merespon dan berinteraksi. 
Selain itu, media sosial dapat juga dijadikan sebagai media promosi untuk memperkenalkan pada apresiator, penikmat seni, kritikus, jurnalis, dan manajemen musik. Salah satunya musisi yang memanfaatkan sosial media salah satunya Instagram yaitu Hendra Kumbara dengan akun Instagramnya @hendrakumbara. Pada tahun 2021 ini di dalam akun Instagram nya sudah memiliki sekitar 71,4 ribu pengikut dengan 834 unggahan. Unggahan tersebut berisikan video hasil pertunjukan, video clip, video promo lagu baru, dan video proses rekaman, video perjalanan tour.

Media sosial memberikan dampak positif bagi profesi sebagai musisi. Penelitian ini membahas tentang bagaimana strategi personal branding musisi melalui media sosial, dalam hal ini media sosial Instagram. Konsep utama yang digunakan peneliti dalam penelitian ini adalah teori personal branding yang berisikan tujuh karakteristik personal branding menurut Mateusz Grzesiak, sebagai berikut: 1) authenticity (keaslian), 2) integrity (integritas), 3) consistency (konsisten), 4) specialization (spesialisasi), 5) distinctiveness (kekhasan), 6) relevant (relevan), 7) performance (kinerja) (Grzesiak, 2018).

\section{Metode}

Perolehan data penelitian ini berasal dari lapangan dengan melakukan pengamatan dan wawancara mendalam dengan informan yang tahu dan mengerti tentang permasalahan yang diteliti. Segala permasalahan diidentifikasi, dibahas, dan dikaji secara mendalam. Selanjutnya diperoleh gambaran atau penjelasan tentang hal-hal yang berhubungan dengan fenomena permasalahan. Model penelitian yang digunakan adalah penelitian interpretatif yaitu penelitian yang menjelaskan strategi personal branding musisi melalui media sosial, khususnya Instagram.

Pada hakikatnya penelitian ini menggunakan metodologi penelitian kualitatif dengan paparan secara deskriptif dan pendekatan perspektif interdisiplin.

Data penelitian kualitatif terdiri atas data primer dan sekunder. Pertama, data primer diperoleh melalui pengamatan langsung dan wawancara. Wujud data primer dalam penelitian ini berupa informasi lisan dan tindakan subjek penelitian. Data bersumber dari para narasumber atau informan yang dapat memberikan keterangan secara langsung dengan masalah penelitian. Kedua, data sekunder berupa bahan informasi secara tidak langsung. Data yang dimaksud bersumber dari arsip-arsip karya, dokumen-dokumen pribadi, dokumen resmi, foto-foto dan catatan lain yang relevan untuk mengungkap permasalahan. Subjek penelitian yang dipilih merupakan key person atau orang kunci ahli yaitu musisi. Penentuan subjek dilakukan secara sengaja berdasarkan tingkat kepentingan, pengetahuan, serta pengalamannya sebagai seniman. Informan penelitian ini adalah musisi dengan Hendra Kumbara yang memiliki akun Instagram @hendrakumbara dan Ndaru yang memiliki Instagram @ndarboy_genk.

Analisis data dalam penelitian kualitatif dimulai dengan menyiapkan dan mengorganisasikan data (yaitu data teks seperti transkrip data atau gambar seperti foto), untuk dianalisis, kemudian mereduksi data tersebut menjadi tema dan terakhir menyajikan data dalam bentuk bagan, tabel, atau pembahasan (Sumaryanto, 2007). 


\section{Hasil}

\section{Personal Branding Musisi Pop Jawa melalui Media Sosial}

Hendra Kumbara merupakan penyanyi Pop Jawa muda berbakat asal Kabupaten Pati, Jawa Tengah yang viral dengan lagunya yang berjudul 'Dalan Liyane' yang berhasil menarik belasan juta penonton di YouTube. Hendra Kumbara lahir di Pati, 12 Agustus 1989, yang merupakan alumni Jurusan Pendidikan Seni Drama, Tari dan Musik dari Universitas Negeri Semarang. Semasa kecilnya, Hendra Kumbara memang sudah tertarik dengan dunia musik dan juga bernyanyi. Hal inilah yang membawa Hendra Kumbara untuk melanjutkan pendidikan di Jurusan Seni Drama, Tari, dan Musik (Sendratasik) Universitas Negeri Semarang pada tahun 2007. Sejak kuliah, Hendra Kumbara sudah sering mengisi ruang panggung pertunjukan. Hendra Kumbara lulus kuliah pada tahun 2012 dan melanjutkan kembali untuk mengasah bakatnya dan semakin serius membangun karir bermusiknya di Kota Semarang.

Memang tidak ada keberhasilan yang instan. Hendra Kumbara terus mencoba dan meneruskan proses berkarya nya. Sampai di lagu ciptaannya yang berjudul 'Dalan Liyane', Hendra Kumbara mendadak viral di tengah-tengah masyarakat Indonesia khususnya kalangan milenial penikmat lagu Pop Jawa. Lagu tersebut sudah dicover oleh penyanyi-penyanyi Nasional seperti Nella Kharisma, Happy Asmara, dan Via Vallen. Terhitung bahwa sudah terdapat sekitar tujuh lagu yang diciptakannya termasuk 'Dalan Liyane' dan 'Wegah Pisah' serta beberapa lagu ciptaan lainnya dinyanyikan ulang oleh musisi lain.

Tidak hanya sebagai musisi dan penulis lagu, Hendra Kumbara juga merupakan pemilik Rumah Produksi 'Syalala Production' yang menciptakan lagu 'Balungan Kere' yang dipopulerkan oleh Ndarboy Genk, yang tentu saja sama populer nya dengan Hendra Kumbara di kancah musik Pop Jawa Indonesia. Meski tengah meraih kesuksesan dengan sejuta bakat yang dimiliki oleh Hendra Kumbara, Hendra mengaku bersyukur dan akan selalu konsisten dengan perjuangannya di belantika musik Pop Jawa Indonesia.
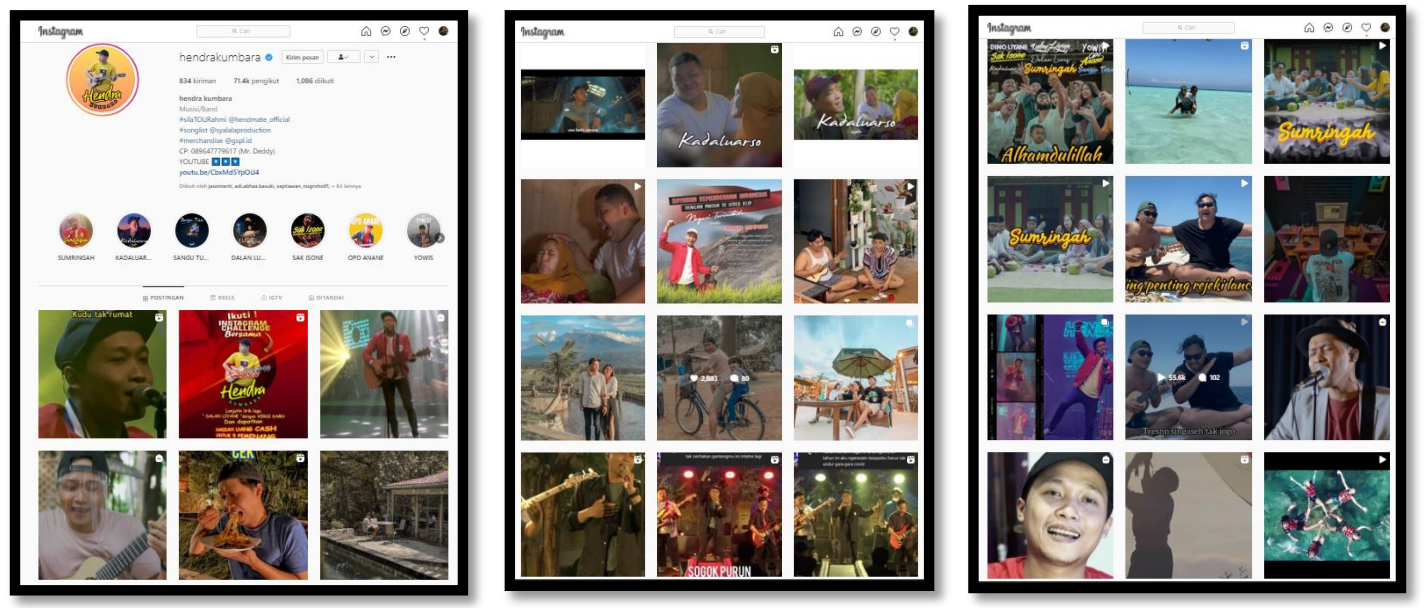

Gambar 1. Tampilan Beranda Instagram Hendra Kumbara Sumber : Instagram Hendra Kumbara @hendrakumbara

Sama halnya dengan Ndarboy Genk yang beberapa bulan terakhir kembali trending hingga viral di berbagai sosial media melalui lagu ciptaannya yang berjudul 'Mendung Tanpo Udan'. Lagu tersebut merupakan lagu ketiga setelah 'Balungan Kere' dan 'Wong Sepele' yang viral dipopulerkan oleh Ndarboy Genk pada tahun 2019. Ndarboy Genk memiliki nama asli 
yaitu Helarius Daru Indrajaya merupakan musisi asal Kota Bantul Yogyakarta dan dikenal dengan lagunya yang menggunakan Bahasa Jawa.

Daru juga salah satu alumni dari Jurusan Pendidikan Seni Drama, Tari, dan Musik Universitas Negeri Semarang yang memiliki perjalanan karir cukup pahit, dari menjadi additional trombonist, vokalis band independent Pingkel Standing, hingga pernah berjualan nasi pecel di pinggir jalan. Namun Daru terus berkarya dan menciptakan karya di sela-sela aktivitas berjualan pecel. Titik balik perjalanan hidup Daru terjadi ketika mempopulerkan Lagu 'Balungan Kere' ciptaan Hendra Kumbara dan puncaknya di lagu 'Mendung Tanpo Udan' yang beberapa bulan terakhir meledak di pasaran karena populer di kalangan pengguna aplikasi TikTok serta didingarkan oleh 9.495 .310 orang melalui platform musik digital Spotify. Daru mengaku tidak pernah mempromosikan secara besar-besaran lagu tersebut karena keterbatasan modal produksi.
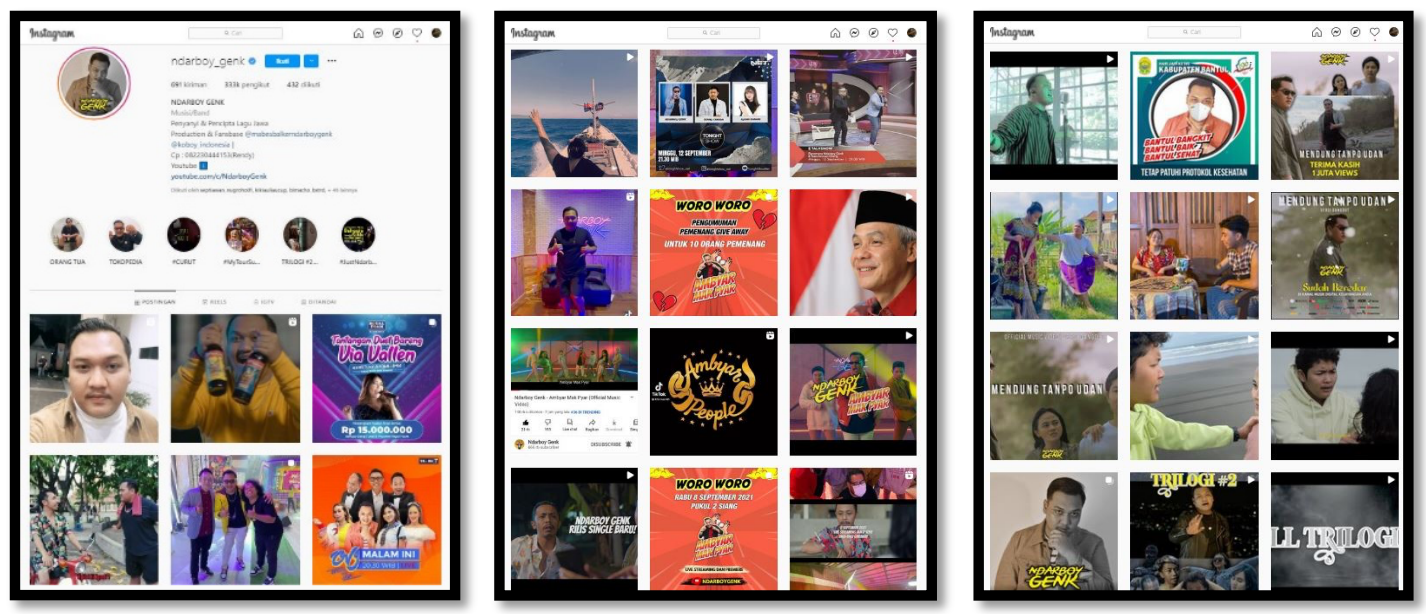

Gambar 2. Tampilan Beranda Instagram Ndarboy Genk Sumber : Instagram Ndarboy Genk @ndarboy_genk

Musik memang tidak lebih dari sekadar fanatisme, selalu mengagungkan jargon akademis demi kepentingan kelompok tertentu. Bahkan muncul pula gerakan-gerakan sepihak yang mengatasnamakan musik demi kepentingan golongan, bahkan pribadi. Musik menjadi alat, lalu tender alat musik dengan distributor besar, kampanye, korupsi, hingga tenggelam dan dibui. Terlepas dari itu semua, musik telah membuat setiap orang masa kini benar-benar "merdeka" menentukan apa yang diinginkan, menyebarkan kemana saja yang diinginkan, menjual semurah-murahnya, bahkan membagi segratis-gratisnya (Septiyan, 2021).

\section{Pembahasan}

\section{Karakteristik Personal Branding Musisi Pop Jawa}

Strategi personal branding kedua Musisi Pop Jawa ini didahului dengan pemenuhan terhadap kriteria personal branding yang ingin dicapai. Kriteria yang digunakan oleh penulis dalam penelitian ini adalah kriteria yang dikemukakan oleh Grzesiak (2018). Dalam membangun personal branding melalui sosial media Instagram sebagai seorang musisi, 
musisi menggunakan fitur audio visual yang diunggulkan oleh Instagram dalam menyampaikan pesan personal branding yang dibentuk.

Situs Instagram ini dapat diakses menggunakan aplikasi ponsel dengan nama yang sama yang tersedia untuk Windows Phone, iOS dan Android. Instagram memperkenankan pengguna untuk mengambil foto dan video, memodifikasi, menerapkan filter digital dan membagikannya di berbagai media sosial lain. Pada April 2012, layanan Instagram ini dibeli oleh Facebook dengan harga sekitar \$1 miliar. Namun, setelah beberapa waktu ada perubahan dalam istilah layanan yang memungkinkan penjualan foto pengguna ke bisnis luar, yang mengakibatkan penurunan jumlah pengguna aktif dari 100 juta pada September 2012 menjadi ca. 90 juta pada januari 2013 (Smith, 2014). Pengguna Instagram rata-rata dari kalangan pengguna iPhone dan Android. Di antara pengguna layanan, $68 \%$ adalah wanita, dan lebih sering digunakan oleh orang-orang yang tinggal di kota-kota besar. Orang-orang di atas usia 35 tahun adalah 90\% pengguna Instagram; 24\% pengguna menggunakan layanan ini setiap harinya (Polasik, M., Piotrowska, A., \& Kunkowski, 2012).

Konten-konten yang diunggah ke dalam akun Instagram pun haruslah memiliki keselarasan dengan ambisi pribadi yang dimiliki. Menurut Roszkowski (2013), penetapan branding dapat memberikan kelebihan suatu produk dan jasa. Nilai yang dibentuk oleh Hendra Kumbara dan Ndarboy Genk dalam menjadi Musisi Pop Jawa adalah sebagai seorang pencipta sekaligus penyanyi yang memiliki reputasi baik dalam perspektif masyarakat pendukungnya. Reputasi terbentuk dari berbagai informasi hasil membanding-bandingkan berbagai informasi tergantung dari expectation-gap dari publik. Reputasi berkorelasi dengan legitimasi jika reputasi positif berarti organisasi/personal memiliki legitimasi (Kriyantono, 2012). Legitimasi diperoleh dari persetujuan komunitas/personal di sekitarnya (Helm et al., 2011).

Sebuah personal brand adalah harapan, citra, dan persepsi yang tercipta dalam pikiran orang ketika melihat atau mendengar sebuah nama. Para individu dapat mencapai keberhasilan di dunia yang kompleks dan penuh persaingan dengan giat membangun kekuatan personal brand. Dengan perkataan lain, personal brand tersebut adalah apa yang dijanjikan, apa yang diperjuangkan, dan yang lebih penting lagi bagaimana melukiskannya kepada orang lain. Brand adalah suatu hubungan yang melibatkan sejens kepercayaan, yang hanya akan terjadi ketika dua orang atau lebih meyakini terdapatnya suatu hubungan yang langsung di antara sistem-sistem nilai mereka. Nilai-nilai tersebut tidak hanya mempengaruhi pikiran, namun juga akan mempengaruhi cara bertindak dan bertingkah laku. Penilaian tersebut kemudian menjadi persepsi yang tertanam di dalam benak orang lain (McNally, David \& Speak, 2004, p. 24).

Karakter yang dibentuk oleh Hendra Kumbara dan Ndarboy Genk membentuk personal branding sebagai seorang musisi Pop Jawa yang produktif, kreatif dan sederhana, tidak memiliki sifat yang neko-neko. Hal demikian sesuai dengan konten yang ditampilkan ke dalam beranda Instagram nya yang lebih mengutamakan kesederhanaan dalam hidup, produktif, kreatif, dan menghibur. Ambisi pribadi yang diterapkan oleh Hendra Kumbara dan Ndarboy Genk memiliki keselarasan dengan karakter yang dibentuk, karena dalam kehidupan sehariharinya sesuai dengan karakter yang ditampilkan dalam konten-konten yang dipublikasikan. Berdasarkan karakteristik yang dimiliki Hendra Kumbara dan Ndarboy Genk dalam perspektif konsep Grzesiak (2018), dapat disimpulkan bahwa kedua individu tersebut telah memiliki aspek authenticity (keaslian). 
Integritas menurut Grzesiak (2018) adalah mematuhi kode moral dan perilaku yang ditetapkan oleh ambisi pribadi. Membentuk dan membangun personal branding yang otentik, tentu harus taat kepada kode moral dan perilaku yang telah ditetapkan oleh ambisi pribadi adalah kunci utama dalam menciptakan personal branding yang dapat dipandang baik oleh khalayak. Perilaku yang telah dibentuk oleh Hendra Kumbara dan Ndarboy Genk sebagai pribadi yang sederhana, produktif, kreatif, dan menghibur. Terlihat pada konten di beranda Instagram nya yang juga seperti pribadi sebenarnya dan tidak diskenario. Selain itu juga Hendra dan Daru selalu melakukan filterisasi terhadap konten yang akan diunggah pada akun masing-masing supaya konten selalu dapat diterima oleh masyarakat pendukungnya dengan baik. Hal demikian menurut penulis telah sesuai dengan konsep integritas menurut Grzesiak, karena dalam sebuah pembentukan personal branding yang otentik haruslah didasarkan pada regulasi yang telah ditetapkan oleh pribadi dan integritas dalam akun Instagram masingmasing.

Adapun pemahaman konsisten dalam buku Authentic Personal Branding milik Rampersad (2008), menyebutkan bahwa individu harus konsisten dalam berperilaku baik dalam dunia nyata maupun dunia maya. Kekonsistenan yang diterapkan oleh Hendra Kumbara dan Ndarboy Genk dalam akun Instagramnya dapat dikatakan telah memenuhi kriteria yang telah membentuk pola yang serupa, baik pada profesinya, kesehariannya, ataupun relasinya. Dalam kaitannya pada akun Instagram Hendra Kumbara dan Ndarboy Genk menurut pengamatan penulis, hal demikian terlihat bagaimana setiap konten yang terdapat pada akun masing-masing memiliki pola, yaitu dilakukan dengan konsisten terkait aktivitas produksi, pertunjukan, dan aktivitas sehari-hari. Demikian yang dapat dikatakan konsisten karena penerapan yang terjadi dalam beranda Instagram untuk membentuk perspektif masyarakat pendukung. Jadi dapat disimpulkan bahwa Hendra Kumbara dan Ndarboy Genk telah konsisten dengan konsep yang sudah disepakati sesuai dengan ambisi diri masing-masing.

Specialization pada akun Instagram @hendrakumbara dan @ndarboy_genk cenderung menampilkan konten yang berisikan proses kreatif, kesederhanaan musisi, dan hiburan. Hal demikian dapat dilihat dari konten yang sering diunggahnya. Penulis menyimpulkan bahwa Hendra Kumbara dan Ndarboy Genk menitikberatkan dirinya ke dalam bagian musisi musisi milenial yang produktif. Unggahan foto dan video dalam akun masing-masing turut menegaskan bahwa dirinya memiliki spesialisasi bidang dan keterampilan yang ditekuninya, yaitu seorang musisi. Distinctiveness dalam buku Personal Brand Creation in The Digital Age oleh Grzesiak (2018) menjelaskan dalam membranding diri perlu diungkapkan dengan cara yang unik dan berbeda dari kompetisi dan kebutuhan guna menambah nilai bagi orang lain. Personal branding perlu didefinisikan dengan jelas agar orang lain dapat dengan cepat memahaminya. Berdasarkan pengamatan dan analisis yang penulis lakukan, Hendra Kumbara dan Ndarboy Genk menekankan dirinya menjadi seorang musisi Pop Jawa milenial yang berkompeten di bidangnya yang memiliki ciri khas masing-masing dalam lagu Pop Jawa ciptaannya.

Ciri khas dalam lagu Pop Jawa menjadi tren sehingga pada akhirnya menjadi unsur pembangun karakteristiknya, seperti : 1) Pola permainan kendang, perbedaan karakteristik lagu pop jawa milenial memiliki pola tabuhan khusus. Pada konteks ini adalah pola permainan kendangnya. Pola tabuh tidak sekadar menggunakan pola chalte (pola tabuh tabla India) 
namun pola tabuhnya lebih variatif. Perpaduan antara chalte dan pola-pola kendang dari berbagai pola tabuh kesenian lokal; 2) Percampuran berbagai Macam Genre sebagai Aransemen, karakteristik ini mencampurkan berbagai genre musik yang dijadikan sebagai pendekatan aransemen. Sejumlah genre musik seperti Pop, Keroncong, Reggae, Ska, House Music, dan lain sebagainya, sering disisipkan pada lagu-lagu Pop Jawa; 3) Senggakan, muncul melalui pola tabuh dari kendang. Masyarakat Indonesia sudah tidak asing dengan kalimat "Buka Sithik Jos". Senggakan jika di karawitan memiliki kesan rame, dengan demikian senggakan dapat diartikan vokal bersama atau tunggal dengan menggunakan cakepan parikan, serangkaian kata-kata (kadang-kadang tanpa makna) untuk mendukung terwujudnya suasana ramai dalam sajian suatu gending. Namun dalam Pop Jawa, senggakan terbentuk oleh stimulasi permainan kendang. Pola tabuh kendang membentuk ruang-ruang kemungkinan munculnya senggakan. Kata-kata yang menjadi senggakan dapat menempel pada pukulan kendang atau pola tabuh, hingga mengisi ruang kosong di mana kendang tidak dimainkan.

Relevant Personal Branding yang dibangun haruslah terhubung dengan persepsi audiens (Grzesiak, 2018). Pada masing-masing akun Instagram nya, Hendra Kumbara dan Ndarboy Genk selalu mengunggah hasil ciptaan lagunya dengan kemasan konten yang berbeda-beda, terkadang dalam bentuk gambar, video teaser, dan audio dengan dilengkapi cover/artwork lagu. Hal demikian selalu berdampak respons yang positif dari followers nya, yang berupa follow, likes, maupun comment serta repost yang dilakukan oleh masyarakat pendukungnya. Penulis menganalisis bahwa relevansi yang dibangun oleh Hendra dan Daru sesuai dengan followers atau masyarakat pendukungnya di Instagram. Karena masyarakat pendukung tentu menganggap bahwa konten dari Hendra Kumbara dan Ndarboy Genk berhubungan serta dibutuhkan oleh masyarakat pendukungnya. McNally dan Speak (2011) menambahkan, relevant merupakan apa yang diwakili oleh merek tersebut berkaitan dengan apa yang dianggap penting oleh orang lain. Adanya pengikut di Instagram memunculkan individu-individu yang selaras dengan siapa yang diikutinya. Penulis menyimpulkan bahwa akun @hendrakumbara dan @ndarboy_genk termasuk ke dalam referensi masyarakat pendukungnya dan menganggap konten Hendra Kumbara dan Ndarboy Genk penting bagi mereka sehingga mereka mulai mengikuti dan menjadi salah satu bagian dari followers akun Instagram Hendra Kumbara dan Ndarboy Genk.

Karakteristik terakhir dalam membentuk personal branding yang otentik adalah performance (Grzesiak, 2018). Dalam menjaga eksistensi menjadi seorang musisi Pop Jawa milenial, Hendra Kumbara dan Ndarboy Genk selalu menjaga interaksi yang baik dengan masyarakat pendukungnya dengan cara tetap mengunggah konten-konten yang menarik pada akunnya. Hal demikian dilakukan untuk tetap menjangkau followers Instagram agar terlihat sebagai akun yang benar-benar memotivasi dan menghibur. Kemudian selanjutnya untuk menjaga keseluruhan personal branding yang telah dibangun, kunci dari segalanya adalah untuk tetap menjadi diri sendiri, yang dimaksud adalah tidak mengubah ataupun keluar dari arus yang telah dibangun oleh Hendra Kumbara dan Ndarboy Genk. Tetap menjalankan setiap unsur karakteristik yang ada untuk menyempurnakan personal branding yang dibangun.

Selanjutnya, Hendra Kumbara dan Ndarboy Genk juga tetap melakukan filterisasi terhadap akun Instagram nya masing-masing. Setiap unsur yang terdapat di beranda Instagram nya selalu diperhatikan. Interaksi kepada masyarakat pendukungnya turut 
dipertimbangkan seperti baik-buruknya suatu komentar yang masuk pada setiap posting-an selalu direspon dan difilter agar tetap menjaga personal branding yang sudah dibangunnya.

Berdasarkan analisis penulis terhadap data yang telah didapat melalui wawancara dengan informan serta pengamatan yang dilakukan melalui akun Instagram @hendrakumbara dan @ndarboy_genk, penerapan ketujuh karakteristik yang dilakukan oleh Hendra Kumbara dan Ndarboy Genk merupakan ambisi pribadi yang selaras dengan keseharian pribadi tanpa dibuat-buat, serta tidak membohongi pribadi dalam menciptakan personal branding yang otentik. Sehingga tercipatalah personal branding yang baik dan bertahan lama. Oleh karena itu sangatlah penting untuk melibatkan pikiran dan perasaan orang lain agar terkait erat dengan personal brand seseorang. Dan ketika sebuah personal brand dapat membangun sebuah hubungan yang erat dengan pikiran dan perasaan orang lain, maka itulah personal brand yang mempunyai kekuatan sesungguhnya (McNally, David \& Speak, 2004, p. 14).

\section{Kesimpulan}

Strategi personal branding oleh Hendra Kumbara dan Ndarboy Genk sebagai musisi Pop Jawa Milenial dengan masing-masing akunnya yaitu @hendrakumbara dan @ndarboy_genk, pada tahun 2021 ini di dalam akun Instagram nya sudah mencapai 71,4 ribu untuk pengikut Hendra Kumbara dan 333 ribu untuk pengikut Ndarboy Genk, yang masing-masing berisikan aktivitas proses kreatif, video clip, aktivitas sehari-hari, promo lagu dan foto-foto dokumentasi saat pertunjukan.

Secara keseluruhan akun Instagram dari Hendra Kumbara dan Ndarboy Genk sesuai dengan ketujuh karakteristik personal branding seperti authenticity. integrity, consistency, spesialization, distinctiveness, relevant, dan performance. Authenticity sebagai musisi Pop Jawa Milenial yang sederhana, produktif, kreatif, dan menghibur. Integrity memiliki konten yang terstruktur, teratur, dan positif, yaitu memilah dan memilihi serta memfilterisasi konten yang akan diunggah maupun sudah diunggah. Specialization bidang musik Pop Jawa. Relevant yaitu dengan banyaknya akun lain yang mengikuti maupun yang memberikan respon baik pada konten Instagram Hendra Kumbara dan Ndarboy Genk. Consistency terlihat pada aktifnya Hendra dan Daru dalam mengunggah konten serta selalu memiliki penggambaran yang serupa dan tertata sehingga semakin memperjelas personal branding nya kepada masyarakat pendukung. Performance dengan menjalin interaksi dengan tetap mengunggah aktivitas baik proses kreatif, pertunjukan, dan aktivitas sehari-hari. Personal branding yang telah dibangun kemudian disatukan dengan media sosial yang dimiliki salah satunya Instagram serta terdapatnya audiens yang menerima pesan personal branding yang disampaikan, maka terciptalah personal brand di benak khalayak.

\section{Referensi}

Grzesiak, M. (2018). PERSONAL BRAND CREATION IN THE. Springer International Publishing. Helm, S., Liehr-Gobbers, K., \& Storck, C. (2011). Reputation management. Springer Science \& Business Media.

Kartajaya, H. (2009). New Wave Marketing. Gramedia Pustaka Utama. 
Kriyantono, R. (2012). PR \& Crisis Management: Critical PR, Etnografi Kritis \& Kualitatif. Prenada.

Mayfield, A. (2008). What is Social Media (AN e-book). ICrossing.

McNally, David \& Speak, K. D. (2004). Be Your Own Brand. Raja Grafindo.

Nally, M. \& S. (2011). Be your own brand: achieve more of what you want by being more of who you are. BerretKoehler Publisher, Moleong.

Polasik, M., Piotrowska, A., \& Kunkowski, J. (2012). Wykorzystanie serwisów społecznos'ciowych w polskim handlu elektronicznym, Zeszyty Naukowe. Studia Informatica, 29, 249-262.

Rampersad, H. . (2008). Authentic Personal Branding. PPM Publishing.

Rohidi, T. R. (2011). Metodologi penelitian seni. Semarang: Cipta Prima Nusantara, 75, 116121.

Roszkowski, J. (2013). Monitoring mediów społecznos'ciowych. In J. Królewski \& P. Sala (Eds.). E-Marketing, 336-373.

Septiyan, D. D. (2021). Apresiasi Lintas Genre Musik Indonesia melalui Synchronize Festival. Musikolastika: Jurnal Pertunjukan Dan Pendidikan Musik, 3(1), 1-8. https://doi.org/https://doi.org/10.24036/musikolastika.v3i1.57

Smith, C. (2014). Here's why Instagram's demographics are so attractive to brands. http://www.businessinsider.com/instagram-demogra\%0Aphics-2013-12

Sumaryanto, T. (2007). Pendekatan Kuantitatif dan Kualitatif dalam Penelitian Pendidikan Seni. Unnes Press. 